\title{
Vegetable Production Challenges in Kpando Municipality: Perspective of Women Farmers
}

\author{
Grace Denny Doku (Corresponding author) \\ Department of Agro Enterprise Development \\ Faculty of Applied Sciences and Technology, Ho Technical University \\ Ho-Ghana \\ E-mail: avliaman@yahoo.com
}

Joyce Mamle Mawusi Obubuafo

Department of Agro Enterprise Development

Faculty of Applied Sciences and Technology, Ho Technical University

Ho-Ghana.

E-mail: mamlejo1@yahoo.com

Margaret Aba Sam Hagan

Department of Agropreneurship

Faculty of Entrepreneurship and Enterprise Development, Kumasi Technical University,

Kumasi

E-mail: aba_hagan13@yahoo.com

Received: March 23, 2020

Accepted: April 25, 2020

Published: May 16, 2020

doi:10.5296/jebi.v7i1.17043

URL: http://dx.doi.org/10.5296/jebi.v7i1.17043

\begin{abstract}
The study sought to evaluate vegetable production by women within the Kpando Municipality. To arrive at the set objectives, data was collected from sampled women who were into vegetable production in the study area. Questionnaire were used to collect data from the respondent on their socio-economic characteristics, production activities and challenges they faced in production and marketing of vegetable in the study area. Descriptive statistics were
\end{abstract}


used to analyze the data collected from the respondents. The results of the study revealed that women in the study area had passion towards agriculture and as high as $33.2 \%$ of the respondents participated in a variety of farm activities. These activities included and preparation, sowing of seeds and fertilizer application. Challenges faced by the respondents included delayed access to inputs, lack of financial assistance (credit) and storage facilities. The paper concluded that productivity of the respondents could be improved significantly by improving women farmers' access to productive resources such as fertilizers and credit. It is therefore recommended that fertilizers should be supplied to the farmers on time and the Kpando Municipal Assembly should liaise with financial institutions to support these farmers financially.

Key words: Vegetable, Women Farmers, Kpando, Volta Region

\section{Introduction}

Kpando Municipality is one of the municipalities in the Volta Region of Ghana and among the oldest districts in the country. Kpando municipality is about $90 \mathrm{~km}$ from Ho (the Volta regional capital) and its location makes it stand as a potential for rapid economic growth.Some of the women in this community engage in trading and few of them are into vegetable production mostly on subsistence basis whiles their male counterparts are into large scale productions of fruits and vegetables as well as other crops for both the export and local markets.

Vegetable production is one of the basic skills of human. Its level of productivity and success depend on local climate and season as well as the range of species cultivated.

The purpose of vegetable production varies from large-scale farm enterprises to private home gardening, where vegetables are essential elements to supplement diets and income. Women are involved in vegetable production on limited scale. There are a lot of reasons for growing vegetables, but the most important reason is for food production. Vegetables are essential in diet, they provide fiber, trace minerals, vitamins, carbohydrates and proteins. Kpando women play a key role in agricultural production. They take part in all activities related to vegetable production and as a result, they are a vital component for the growth and development of the community.

Rural women, as well as men, throughout the world are engaged in a lot of agricultural activities that are important to agricultural productivityand economic growth as well as the well -being of individual households. Yet the enormous contribution of women in agricultural production continues to be unrecognized compared to activities undertaken by men in the field.

Although the main occupation of the people within Kpando Municipality is farming, quite a number of the women are into agricultural production, even though, their contributions are not specified nor quantified. Moreover, their production is hindered by several challenges. The study, therefore, sought to identify the challenges the women faced in production of vegetable in the municipality. 


\section{Literature Review}

\subsection{Importance of Vegetable Production}

Agriculture is the main pillar of Ghana's economy, the largest contributor to Gross Domestic Product (GDP), accounting for about $51 \%$. It provides $45 \%$ of all export earnings, $12 \%$ of tax revenue and it is the main employer of the Ghanaian population, supporting at least $80 \%$ of the total population economically through farming, distribution of farm produce and provision of other services to the agricultural sector. Agriculture further contributes to the development of industry through the supply of raw materials. Fifty five percent $(55 \%)$ of the total population is engaged in agriculture and just under half $(48.7 \%)$ of the total female population is self-employed in the same sector. Furthermore, women account for about $70 \%$ of total food producing population in Ghana. Under the current macro-economic frame work of the government, agriculture was expected to play a lead role in achieving the target of 5\% GDP growth rate by 2005 . In more specific terms, growth in the sector was expected to rise from $4.1 \%$ per annum in 2002 to $4.8 \%$ by 2005 (Ghana Poverty Reduction Strategy (GPRS) (2003-2005).

Vegetable production is one of the key aspects of Ghana's agricultural sector. This is because vegetables are important component of food for the household. Although the actual quantity of carbohydrates, protein and fats may be limited in some vegetables, the real value of vegetables lies in the minerals, vitamins and fibre in fresh vegetables. When farmers produce vegetables on their own lands, freshness is guaranteed. Vegetable production is a form of intensive agriculture. Very small areas of land can yield large volumes of produce, so long as the plants are provided with adequate water, nutrients as well as pest and disease management in the field (with good management practices). Fresh vegetables make up an important part of the human diet and surplus vegetables from the farm usually find ready market, and this has the potential of providing a valuable source of family income to the farmer.

\subsection{Vegetable Production by Women}

Policy makers as well as administrators typically still assume (in the face of the empirical data) that men are the farmers and women play only "supportive role" as farmers' wives (Samanta, 1994). It has been widely demonstrated that rural women, as well as men, throughout the world are engaged in a range of productive activities essential to household welfare, agricultural productivity, and economic growth.Rural women farmers play a vital role in food production and food security. They account for $70 \%$ of agricultural workers, $80 \%$ of food producers, and $100 \%$ of those who process basic foodstuffs as well as undertake from $60 \%$ to $90 \%$ of the marketing (Fresco, 1998). Four out of ten agricultural workers in the world are women (U.N. 1986).

More than one quarter of the world population is made up of women and thirty percent $(30 \%)$ of agricultural work in industrialized countries is undertaken by women. In developing countries, this proportion is higher (FAO. 2000). Rural women play a key role in agricultural production. They are responsible for performing several activities from land preparation to 
the harvest of their various crops. Women are involved in vegetable production on limited scales. They grow vegetables in and around their homes however women role in this respect appear to be dormant.

Theratio of female employment in agriculture to that of male workers is higher in south Asian countries. Women participation in the sector of agriculture is very active as they play varied roles as agricultural laborers and household heads or as managers of their various household activities. As observed, south Asian women perform work four hours more than their male counterparts (Human Development Report 2002). The contribution of women to agriculture in south Asia is greater than men but their roles and efforts remain unappreciated and unacknowledged. Their social as well as economic values of work most of the time are under recorded and under-estimated (Syal 2004; Shahzad 2004).

Activities such as land preparation, sowing as well as fertilizer application performed by men are accomplished within a specific time period while in comparison, activities such as weeding and recurrent daily tasks undertaken by women lasts from the time of planting till harvesting is done. In spite of spending the same amount of time on activities related to agriculture, the work performed by women in general tends to be less visible and of lower value compared to that of men. The produce of women is often battered than sold and this contributes to their perceived lower contribution to the rural economy.

About seventy percent (70\%) of the female labour force is engaged in the agricultural sector and they contribute in all the operations related to crop production. This includes seed sowing, weeding, fertilizer application, pest management and harvesting. Threshing, winnowing and livestock work such as milk production, animal care, fodder cutting among others are also engaged in by women (Rashidi 2004). The participation of women contributes to $25 \%$ - $45 \%$ of labour input in the rural economy. The share of women in agriculture and its related activities is $69 \%$ compared to that of men which is $38 \%$. Almost $36 \%-38 \%$ of women work on their own family farms (ESCAP 1997). The participation of women in the agricultural labour force rose from $9.9 \%$ in $2001-2002$ to $13.5 \%$ in $2005-2006$ (Saeed et al 2007).

Varieties of vegetables are grown all year round for family need and women have played major role in its productive activities for which they carryout substantial volume of work. Women also perform activities for commercial production of vegetable. It has been observed that in farm-families, the participation of woman during decision making as well as in the implementation and management of farm planning was very poor, although their contribution towards total land and labour was significant. At the national level, women participation in the society from planning to execution plays a significant role in sustainable development of any enterprise (Srivastava, 2013)

Women take part actively in farming activities and in processing farm products, in addition to their domestic and reproductive responsibilities. It is often stated that women are responsible for more than half the world's food production and produce up to 60 to $80 \%$ of basic foodstuff in Africa (Fresco, 1998). The role women play in agriculture and the rural society is fundamental to agricultural and rural development in sub-Saharan Africa. The Technical Centre for Agriculture and rural cooperation (CTA, 1993) reported that women in Africa 
make up more than one third of the work force.Most low-income women in developing countries live and work in rural areas, and agriculture is their primary source of employment.

They work on their own plots and those of others; they work as unpaid or paid workers, employers and employees, and as wage-laborers in both on- and off-farm enterprises. Women are deprived equal rights and opportunities. They are denied access to financial as well as economic resources in societies and these factors have resulted in making them poorer than men. Many rural women are illiterates and have less time to know about the latest advances of technology in relation to farm work. They are generally occupied with multiple occupations ranging from unpaid family labour to self-employment in their villages or outside in order to generate income for themselves. However, women in rural areas have affinity towards agriculture and as high as $75 \%$ of rural women participate in variety of farm and other related works (Sadangi, et al 1996). As reported by UNDP (1997), the rural female participation rate in agriculture and livestock is higher (79.4\%) as compared to rural men $(60.8 \%)$ but the women work is not considered as paid work (FAO, 1998).

Women's substantial contribution continues to be undervalued in conventional agricultural and economic analysis and policies, while men's contribution remains the central, often sole focus of attention (Jiggins et al., 1998; Fabiyi et al., 2007).

The empowerment of rural women is absolutely important for raising their status in the various societies. Women need to be recognized as well as treated as workers and they should be provided with healthy and safe working conditions (Zafar, 2005). As theWorld Bank (2008) has stated, failure to recognize women potential in agriculture is a contributing factor to the slow pace of improvement in agricultural development and food security.

\subsection{Vegetable Production Challenges}

It has been reported by different authors that inadequate information about the improved technologies is one of the constraints in agricultural production. Women do not have adequate access to agricultural information and innovations (Saito and Surling, 1993). Women farmers generally have less contact with extension agents than men, especially in communities where male-female contact is culturally restricted. Extension services most of the time is deployed by male agents to men farmers on the erroneous assumption that the message will trickle down to women. In fact, agricultural knowledge is transferred inefficiently or not at all from husband to wife. Also, extension messages tend to ignore the unique workload, responsibilities, and constraints facing women farmers.

Extension service has a significant impact on productivity and output. However, the effectiveness of extension service has been limited inadequate number of extension officers as well as lack of adequate mobility and commitment. Most women farmers are not reached by extension agents and their participation is very limited. In the few cases where women have the opportunity to take part in extension programs, their reproductive roles would not permit them. This makes them to lack access to relevant agricultural information and technical training. This makes it difficult for women vegetable farmers to sufficiently improve their production practices. 
Besides the deficiency of extension programsin targeting women farmers, lack of formal education and high levels of illiteracy among women is another constraint to women receiving extension services. Two-thirds of the one billion illiterate persons in the world are women and girls, and as a result, only 5\% extension services focus on women. Such trainings are mainly on household tasks for women and not on professional crop production activities (FAO, 2003).

It has been noted that extension services have been biased towards larger commercial farmers to the neglect of women producers according to Milimo (1991).

In cases where male extension officers are faced with challenges of extending messages which are perceived to be female related, they require support of female extension officers but because of their relatively fewer numbers, this serves as a brake on their capacity to deliver effective service. Agricultural extension programs as well as other supporting services have traditionally concentrated on educating male farmers hence, women still largely depend on their husbands for relevant agricultural information. Also, because women generally do not own land or other assets, it has traditionally been difficult for women to obtain bank loans or other forms of credit through the banking system. Only $10 \%$ of women have access to credit facility. This makes lack of agricultural credit a challenge for women farmers.

Rural households depend on agricultural lands but access to land is associated with higher incomes and the lands tend to be unevenly distributed among males and females with the men getting the largest share. This situation makes the women to possess less fertile lands compared to their male counterparts. The underlying factors causing this inequality include inheritance and land titling laws which favor men. Traditionally, land is obtained through village heads or lineage and this model still persists although there is an increase in private or state ownership of land. However, women have no role to play in this process due to the occupancy of stools and family headship, which is dominated by men.

In many traditional settings, women cannot inherit land. They are given food plots by their husbands and are not permitted to grow cash crops. When lands are being shared, there is a great dependency on perceptions of the individual's need for the land. As a result, women are given smaller portions because they are perceived to be less capable of farming (Milimo, 1991). Land tenure system is largely by inheritance. The lack of title to land, according to (Famoriyo, 1979) prevents women from exercising or improving their expertise in crop production and animal husbandry because of security of tenure. Majority of them use low yielding and unimproved planting materials, primitive and labour intensive farm implements, traditional farming practices, which have adversely affected agricultural production. Famoriyo (1979) stated that land is the vital possession of the people, without land, farming cannot take place. Searching for the way out of poverty, majority of women take to farming, but the constraint of land limit their performance.

With increasing population pressure and as agricultural production moves away from the use of traditional tools such as cutlass and hoes to a more mechanized farming, the role of women in agriculture declines. Odoemelam et al (2014) have reported that there are differences between the yields of crops cultivated by male and female farmers not because the females 
are less skilled than the males but rather, the females are hindered by access to agricultural resources and inputs.

\section{Methodology}

Kpando Municipality is one of the Municipalities in the Volta Region of Ghana and it is one of the oldest in the country. The Municipality lies within Latitudes $6^{\circ} 20^{\prime} \mathrm{N}$ and $7^{\circ} 05^{\prime} \mathrm{N}$, and Longitude $0^{\circ} 17^{\prime}$ E. It shares boundaries with Biakoye District in the north, Afajato South to the East and North Dayi District in the south. The Volta Lake, which stretches over $80 \mathrm{~km}$ of the coastal line, demarcates the western boundary. The Municipality covers approximately a total land area of 820 square kilometers representing $4.5 \%$ of the Volta Region with almost $30 \%$ of the land submerged by the Volta Lake. The municipality is characterized by two rainy seasons and the average annual rainfall ranges from $900 \mathrm{~mm}$ to $1,300 \mathrm{~mm}$.

The municipality is basically dominated by agricultural activities and it is estimated that about $62 \%$ of the active population is engaged either directly or indirectly in this sector. The climatic condition of the municipality favorably supports variety of crops and livestock production. Food crops such as maize, rice, plantain, cassava, yam and other vegetables especially garden eggs, Okro and chili pepper are grown both on subsistence and commercial levels. Crop production is largely rain-fed even though there are water sources suitable for irrigation (Kpando Municipal Assembly, 2006).

Information regarding the contribution of women to vegetable production was mainly obtained from primary and secondary sources. The respondents were selected from the Kpando municipality using purposive sampling. Target population for the study was women who were into vegetable production at the time of data collection. The list of women who were into vegetable production was collected from the municipal agricultural office in Kpando. Out of this list, a total of forty respondents were selected for the study. The researcher selected ten women farmers each randomly from four farming communities within the municipality with the help of Agricultural Extension Agent. The researcher made use of interviews and questionnaires with support of enumerator due to the high illiteracy rate among women vegetable farmers within the municipality. The enumerators read and interpreted the questionnaire to the respondents in the local dialect whiles responses received were recorded in English. Women farmers who could read and write were allowed to give their own responses. Descriptive analytical methods were used to analyze the responses. The collected data from the field were subjected to the Statistical Package for Social Science (SPSS) and raw figures were obtained in tabulated forms. Graphs used were generated by the use of statistical software including MS Excel and SPSS.

\section{Results and Discussion}

\subsection{Socio-Economic Characteristics of the Respondents}

The distribution of respondents by age, as presented in Table 1 was as follows: Ten (10) respondents $(25 \%)$ were between the ages of 18 and 30 years. For the age groups $31-43$ and 44 and above years, each of them had Fifteen (15) respondents $(37.5 \%)$ therefore, views leading to the conclusion drawn from the research could be largely ascribed to the farmers' 
population within these age groups. Also, a significant dependence can be laid on among the respondents that fell within the age range of 18 to 30 respondents representing $25 \%$ of the sample interviewed as they represent averagely fair views that this research might come out with.

From the Tablelbelow, the educational background of respondents showed clearly that 14 out of the 40 respondents had primary school education, 7 had competed JHS, 8 had technical, vocational or secondary education, 2 had tertiary education while 9 of the respondents had non-formal education. This means that majority of the respondents at least had some form of formal education. It is quite clear that the level of education among women in the study area is very low.

Table 1. Socio-Economic characteristics of the respondents

\begin{tabular}{llll}
\hline Variable & Sub-level & Frequency & Percentages \\
\hline Age & $18-30$ yrs & 10 & 25.0 \\
& $31-43$ yrs & 15 & 37.5 \\
Educational level & 44 and above & 15 & 37.5 \\
& Primary & 14 & 35 \\
& JHS & 7 & 17.5 \\
& Secondary/vocational & 8 & 20 \\
& Tertiary & 2 & 5 \\
Years of vegetable production & Non-formal & 9 & 22.5 \\
& $1-5$ years & 17 & 42.5 \\
& $6-10$ years & 20 & 50.0 \\
Land acquisition & $11-15$ years & 3 & 7.5 \\
& Hiring & 14 & 35 \\
& Inheritance & 15 & 37 \\
Size of farm under cultivation & Share cropping & 11 & 28 \\
& 0.25 acre & 1 & 2.5 \\
& 0.5 acre & 9 & 22.5 \\
& 1 acre & 16 & 40.0 \\
& 1.5 acres & 7 & 17.5 \\
& 2 acres & 7 & 17.5 \\
\hline
\end{tabular}

Source: Survey, 2015.

The work experience presented in Table labove shows that, half of the respondents $(50 \%)$ had been in the vegetable production business for 6 to 10years, $42.5 \%$ also had $1-5$ year of experience. $7.5 \%$ of the respondents had11 to 15 years of vegetable production experience. This result shows that majority of the producers had more than five years of experience in the business and this is expected to result in improvement in their production levels.

According to majority of the respondents, as indicated in Table 1 above, land used for their 
production were very scarce. When a question was posed on how they got their land for vegetable production, about $35.0 \%$ acquired the land by hiring, $37 \%$ by inheritance and $28 \%$ by shared cropping, that is, lands were released for the production after which produce are shared in a certain proportion with land owners. Quite a number of them (37\%) owned the land as properties left for them by their parents or as a family property. This is contrary to the assertion by Milimo, (1991) that women do not own land, they are given food plots by their husbands and are not permitted to grow cash crops. The results, however, indicates that majority of the producers do not own the land they farmed on. This means, they do not have the title to the land, according to (Famoriyo, 1979), and this prevents the women from exercising or improving their expertise in crop production and animal husbandry because of they do not have security of tenure.

In relation to the farm size of vegetable farm cultivated by respondents, $17.5 \%$ of the respondents cultivated 1.5acres which was the same for those who cultivated 2acres. $22.5 \%$ had a land size of half an acre $(0.5$ acre $)$ while 1 respondent $(2.5 \%)$ cultivated a quarter of an acre $(0.25$ acre). As many as 16 respondents $(40 \%)$ cultivated 1 acre of land. This result shows that women in the vegetable crop production in the study area cultivated relatively smaller parcels of land. This confirmed what Milimo, (1991) said that when lands are being shared, there is a great dependency on perceptions of individuals need for land to the extent that women are given smaller portions because they are perceived to be less capable of farming. Another thing that could also lead to the small sizes of farms within the study area can be the demand and storage of harvested produce in case produce were not purchased within the shortest possible period.

\subsection{Type of Vegetable Produced}

Data collected from the study area showed that farmers who cultivated only one kind of vegetable were not many as only $25.0 \%$ of them grew only one kind of vegetable. From figure1 below, it was observed that respondents attached more importance to mixed cropping than mono cropping. Many respondents cultivated two or more vegetables. According to the respondents interviewed, their options for more than one crop had to do with the demand on the local markets around them as well as their neighborhoods. Other reasons they gave were the changes in vegetable prices on the market as in certain times one vegetable fetches high price and vise-versa in another time. This is an indication that, women in vegetable production would like to maximize profit and therefore, produce several vegetables to meet the market demand. 


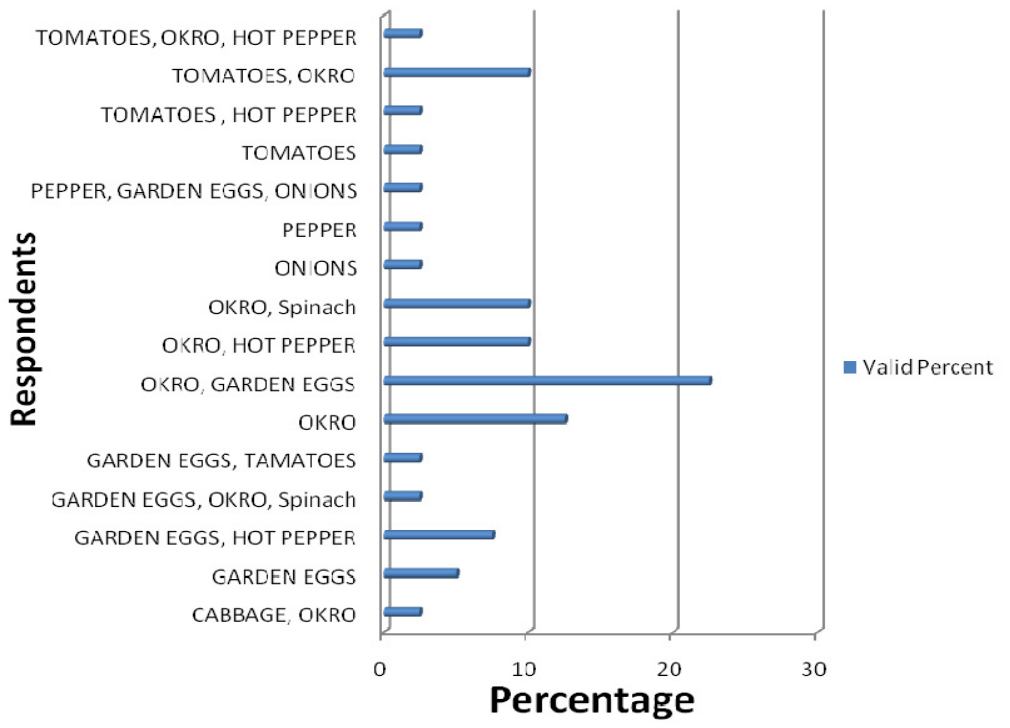

Figure 1. Types of Vegetable Produced By Respondents

Source: Field survey 2015.

\subsection{Marketing of Produce}

Freshly harvested produce (vegetables) from farms were sent to various places for sale. Figure 2 below shows responses collected from the field survey in relation to how and where produce was sold after harvest. Fourteen (14) Vegetable farmers representing $35 \%$ of the respondents sold their vegetable to the consumers in their neighborhoods while $6(15.0 \%)$ sent their harvested produce to the local market for sale. The majority of the respondents $(50 \%)$ produced the vegetable to feed both the neighborhoods and the local market. This might be as a result of the small land sizes used for production, as vegetables produced on the small scale were not simply enough to feed the larger market. The researcher also observed that the farmers who cultivated more than one kind of vegetable were those who supplied to both their neighborhoods and local markets.



Figure 2. A doughnut chart showing how respondents market their produce Source: Field survey 2015. 


\subsection{Access to Farm Inputs and Type of Inputs Received}

With respect to the availability of farm input, as presented in Figure 3 below, 20 of the respondents $(50 \%)$ indicated that they did not receive any kind of farm input from the government, while the other $50 \%$ interviewed said they received farm input for their vegetable production. $85 \%$ of the respondents who received farm inputs were supplied with fertilizer while $15 \%$ received agro chemicals to boost their production. Other farm input such as viable seeds and cash or loans were provided by the farmers themselves. Respondents indicated that the fertilizers they received were somehow affordable because they were subsidized by the government.



Figure 3. A Conical graph of respondents on whether they receive farm input or not and which kind

Source: Field survey 2015

\subsection{Challenges Faced by Vegetable Farmers}

According to the vegetable farmers they encountered many problems which hindered their ability to produce vegetable in large quantities to meet their customers demand. Some of the challenges faced by women vegetable producers within the Kpando Municipality were;

1) Delay in fertilizer supply

2) Government not paying attention to local farmers

3) Lack of finance (credit)

4) Lack of ready market

5) Lack of storage facility

6) Low demand of produce

7) Poor fertility of land 
8) Irregular rainfall patterns

9) Difficulties in land acquisition

10) Poor road network leading to difficulty in transporting produce to the nearby markets

11) Unavailability of irrigation system for all year-round farming.

\section{Conclusion and Recommendation}

The following conclusions were derived based on the results and observation made during the analysis of data collected, focusing on the objectives of the research.

It was identified that women in the study area hadpassion towards agriculture and as high as $33.2 \%$ of these women participated in variety of farm activities and other related works. Activities such as land preparation, seed sowing as well as fertilizer application were performed by women from the time of planting till harvesting was done. This is in agreement with Rashidi (2004) who reported that about seventy percent (70\%) of the female labour force is engaged in the agricultural sector and they contribute in all the operations related to crop production.

In addition, it was revealed that, Agricultural extension programs as well as other supporting services had traditionally concentrated on educating male farmers, and hence women still largely depended on their husbands for information on farm inputs and other resources. It can be concluded that women do not have adequate access to agricultural information and innovations therefore the great absence of extension service had a significant impact on productivity and output of the vegetable producers within the Kpando Municipality.

The research also examined factors that hindered women contribution to vegetable production in the municipality. The challenges identified included; delay in fertilizer supply, government not paying attention to local farmers, lack of finance (credit), lack of ready market, lack of storage facility, low demand of produce, poor fertility of land, irregular rainfall patterns, difficulties in land acquisition, poor road network leading to difficulty in transporting produce to the nearby markets and unavailability of irrigation system for all year-round farming.

Based on the conclusions drawn, the study recommended that:

Land should be made easily accessible to women vegetable producers so they can increase or expand the current sizes of area under cultivation. This will help these women to be able to supply their municipality as well as the national vegetable needs and consequently, improve upon their standard of living.

Government in conjunction with the Ministry of Food and Agriculture (MoFA) should give attention to these all-important crop producers in the country by making the necessary farm inputs (including extension service) readily available to them to ease their farming activities as well.

Finally, the role of women in agriculture should be given much recognition and more 
deserving women farmers should be honored during the annual national farmer's day celebrations. Women issues should be prioritized in the formulation of agricultural policies.

\section{Acknowledgements}

The authors are especially indebted to Hoetu Sophia Yawa of the Department of Agro Enterprise Development of the Faculty of Applied Sciences and Technology, Ho Technical University, Ho Ghana.The authors are also grateful to the respondents(women vegetable producers) in the Kpando Municipality in the Volta Region and the anonymous reviewers who reviewed the paper.

\section{References}

CTA. (1993). A woman's rightful place. Spore bi-monthly bulletin. Technical Centre for Agricultural and Rural Cooperation (CTA), Netherlands. No. 44.

ESCAP. (1997). Women in Pakistan: A country profile. United Nations New York. Exploration, 8(3), 296-307.

Fabiyi E. F., Danladi, B. B., Akande, K. E., \& Mahmood, Y. (2007). Role of Women in Agricultural Development and Their Constraints: A Case Study of Biliri Local Government Area, Gombe State, Nigeria. Pakistan Journal of Nutrition, 6(6), 676-680. https://doi.org/10.3923/pjn.2007.676.680

FAO. (1998). Women, agriculture and rural development in the near east: findings. An FAO study.

FAO. (2000). United Nations Statement on food security in Pakistan.

FAO. (2003). Helping to build a world without hunger, FAO conference, Thirty-Second Session, Rome, Italy.

Farnoriyo, S. (1979). Land Tenure and Agricultural Development in Nigeria, NISER, Ibadan.

Fresco, L. O. (1998). Higher Agricultural Education: An opportunity in rural development for women. Sustainable development department, Food and Agricultural Organization (FAO), for the United Nations.

Human Development Report. (2002). Mahbubal Haq Human Development Centre. Oxford University Press, Islamabad. Pakistan.

Jiggins, J. R., Samanta, K., \& Olawoye, J. E. (1998). Improving women farmers' access to extension services: Food and Agriculture Organization of United Nations, Rome.

Kpando Municipal Assembly. (2006). Retrieved from http://kpando.ghana

Milimo, J. T. (1991). land tenure and agricultural development in eastern province.

Odoemelam, L. E., Alammba, C., \& Lekan-Akomolate, C. N. (2014). Evaluation of women Access to Rights to Land and its Implications on Rural Household Food Security in selected Rural Communities, Abia State, Nigeria. 
Rashidi, A. (2004). Rural Women at Work. Dawn News. Pakistan

Sadangi, B. N., Anand, M. B., \& Patel, J. B. (1996). Socio- personal dimensions of participation of women in farm activities. Indian Journal of Extension Education, 32(1-4), 30-34.

Saeed, B., Aslam, M. R., Makbool, Z., \& Ijaz, A. (2007). Retrieved from http://www.westender.com.au/stories

Saito, K. A., \& Surling, D. (1993). Developing agricultural extension for women farmers. World Bank Discussion paper, 5, 20-25.

Saito, K., \& Weidemann, C. (1990). Agricultural Extension for Women Farmers in Africa. Washington, DC: The World Bank.

Samanta, R. K. (1994). They reap less than they sow. The Hindu (April), No. 7. Madras: India.

Shahzad, M. (2004). Daughters of the soil.

Srivastava, P. L. (2013). Women participation in vegetable production on commercial basis in Rural Ballia. Asian J. Home Sci., 8(2), 796-797.

Syal, H. N. (2004). WTO and working conditions of women in Pakistan. SDPI Research and news bulletin, 11(1). http://www.sdpi.org/help/research and news bulletin/nbjanfe04/articles/WTO.htm

UNDP. (1997). Human Development Report, Oxford University Press, New York. Retrieved from http://www.fao.org

World Bank. (2001). Attacking Poverty, World Development Report (2000-2001). http://www.worldbank.com

World Bank. (2008). Nigeria: Women in Agriculture in: Sharing Experience Examples of Participating approaches. The World Bank: Participating Source Book. Washington, D.C. http://www.worldbank.org/nobi/publication.html

Zafar, I. (2005). Female labour force in agriculture.

\section{Copyright Disclaimer}

Copyright for this article is retained by the author(s), with first publication rights granted to the journal.

This is an open-access article distributed under the terms and conditions of the Creative Commons Attribution license (http://creativecommons.org/licenses/by/3.0/). 